\title{
The Effect of Form versus Meaning-Focused Tasks on the Development of Collocations among Iranian Intermediate EFL Learners
}

\author{
Reza Pishghadam (Corresponding author) \\ English Department, Ferdowsi University of Mashhad \\ PO box 9177948974, Park Square, Ferdowsi University, Mashhad, Iran \\ Tel: 98-915-307-3063Ｅ-mail: rpishghadam@yahoo.com \\ Ebrahim Khodadady \\ English Department, Ferdowsi University of Mashhad \\ PO box 9177948974, Park Square, Ferdowsi University, Mashhad, Iran \\ Tel: 98-915-157-0733 E-mail: ekhodadady@yahoo.com \\ Naeemeh Daliry Rad \\ Azad University of Garmsar \\ PO box 3581631167, Daneshjo Street, Garmsar, Iran \\ Tel: 23-242-26-999 E-mail: naeeme_daliryrad@yahoo.co.uk
}

Received: October 29, 2010 Accepted: November 12, 2010 doi:10.5539/elt.v4n2p180

\begin{abstract}
This study attempts comprehensively to investigate the effect of form versus meaning-focused tasks on the development of collocations among Iranian Intermediate EFL learners. To this end, 65 students of Mashhad High schools in Iran were selected as the participants. A general language proficiency test of Nelson (book 2, Intermediate 200A) was used to measure their general language ability. Moreover, a teacher-made collocation test was implemented to examine the participants' collocation knowledge. Participants were divided into: form-focused instruction group (FFI), meaning-focused instruction (MFI) group, and a control group. The FFI group performed dictogloss task (DT) which focused on both target items and meaning. The MFI group assigned communicative task (pair /group discussion task) which did not required attention to the target items. The control group is designated as the Conventional Group, simply to reflect the fact that they did not receive focus-on-form instruction but rather received combination of explaining collocation or new vocabulary and reading a text silently to mention its main idea or answer to comprehension questions. The results revealed the fact that FFI group (dictogloss task) significantly outperformed the other two groups on the collocation test.
\end{abstract}

Keywords: Collaborative dialogue, Collocation, Dictogloss task, Focus on forms, Focus on form, Focused task, Form-focused instruction.

\section{Introduction}

In second language acquisition (SLA), there has been controversy whether formal instruction is effective or not. While some researchers claim that SLA automatically takes place in any environment where the learners exposed to input, others maintain that a conscious attention to form is necessary (Long, 1991; Norris \&Ortega, 2000; Ellis, 2000; Doughty \& Williams, 1998). They believe that second language learners could not achieve high levels of linguistic competence (Grammar, vocabulary, phonology) from entirely meaning-centered instruction. Thus, they concluded that instruction makes a difference in SLA and mere exposure to input does not lead to develop into accurate acquisition.

FFI can be of two types: Focus on Forms and Focus on Form. "Focus on forms is evident in the traditional approach to grammar teaching based on structural syllabus." (Ellis, 2008, p.962). Whereas, Long (1991, p.46) stated a 'focus on form' is a type of form-focused instruction; it 'overtly draws learners' attention to linguistic elements as they arise incidentally in the lesson whose overriding focus is on meaning and communication'.

Doughty and Williams (1998, p.4) stated "focus on form and focus on forms are not polar opposite in a manner that form and meaning have been regarded. A focus on form entails a focus on the formal elements of the language; whereas focus on forms is limited to such a focus, and focus on meaning exclude it". They suggested that focus on 
form involves a prerequisite engagement in meaning before attention to linguistic features can be expected to be effective.

Ellis, Loewen and Basturkmen (2006) described focus on form episodes as involving brief 'time-outs' from the attempt to communicate, "learners switch backwards and forwards from treating language as a tool for communication and functioning as language users to treating it as an object and functioning as teachers and learners" (p.137).

Moreover, Doughty and Williams (1998, p. 212) declared "it is likely that focus on form can enhance lexical acquisition. And there is mounting evidence that, in the acquisition of lexical items, as with that of grammatical structures, some interaction is helpful" (cited in de la Fuente, 2006). Paradowski (2007) has stated that focus on form acts as an intake or acquisition facilitator, helping the learners perceives the feature under explanation in subsequent meaning-focused in which can then become intake.

The "Noticing Hypothesis", which provided the theoretical underpinning of FFI, claims that learners must consciously notice forms in the input in order to acquisition occurs. The noticing hypothesis is compatible with the claim that FFI can aid acquisition by drawing learners' attention to forms in the input (cited in Ellis, 2001).Long and Robinson (1998, p.24) mentioned "the intended outcome of focus on form is noticing". Focus on form may help learners noticing the gap in their own interlanguage (IL) abilities. Thus, the production of uptake may indicate that a linguistic form has been noticed.

Loewen (2003) argued that focus on form permits learners to time-out from focus on meaning to notice linguistic items in the input. Such a noticing is necessary for second language learning: noticing linguistic items, noticing the gap between models of the target language (TL) and their own language production.

Ellis, Basturkmen, and Loewen (2002) expressed three types of form-based instruction, focus-on-forms, planned focus-on-form, and incidental focus-on-form.

Ellis (2001) stated planned focus on form (enriched input and focused communicative) has drawn extensively on the computational model of SLA which is related to input and production. Enriched input states learners are invited to focus on meaning which are incidental rather than intentional. The aim of it is to include noticing of the target form in the context of meaning focused activities. Various options exist for enriched input such as: input flood, and input enhancement. The former includes plentiful exemplars without any device to draw attention to the feature. Acquisition takes place as a result of frequent exposure to a target feature. On the other hand, input enhancement highlights the target feature. So, it draws learner attention to it. Focused communicative activity intends to result in learners are employing some features that has been targeted. The primary focus is on meaning rather than form. Thus, in focused communicative tasks any acquisition of the target feature that occurs is incidental.

Two principal ways of attempting to include a specific focus on form into task-based teaching are: (I) By means of focused tasks which are designed to focus learners' attention on specific properties of linguistic features. (II) By incorporating a focus on form methodologically into the performance of linguistically unfocused tasks. This includes incidental attention to form that can be preformed preemptively or reactively through feedback. It can be instant as an immediate response to learners' error, or delayed till the end of communicative tasks (R. Ellis, 2003). Moreover, he has suggested three principal ways that researchers set about designing focused tasks: Structured-based production tasks (Dictogloss and text reconstruction tasks), Comprehension tasks (Interpretation task), and Consciousness-raising tasks

$\mathrm{He}$, also, declared dictogloss meet the essential requirements of a task. The primary focus of attention is on meaning, learners can choose their own linguistic resources when reproducing a text although they can use their notes they wrote as they listened, and there is a clear outcome (the reproduction of the text). The success of this task is determined in term of its propositional rather than linguistic content. "The 'focus' comes from the 'seeding' of the original text" (p.156).

Wajnryb (1990) introduced dictogloss and stated "Students individually try to write down as much as they can, and subsequently work in small-groups to "reconstruct" the text; that is, the goal is not to reproduce the original, but to 'gloss' it using their combined linguistic resources" (p. 12).

Therefore, there is a paucity of research in the educational context in Iran in this field especially collocations, this study is aimed at analyzing English teaching and learning in the context of education in Iran from practical perspectives, in light of theory of 'focus on form' . In other words, it seeks to reveal whether form-focused tasks (dictogloss) or meaning-focused tasks (discussion) have any effect on the development of collocation among intermediate learners. To this end, this study was implemented in order to understand the amount of collocation development after 13 sessions of treatments. 


\section{Purpose of the Study}

There seems a paucity of research on the effect of form-focused versus meaning-focused tasks on the development of collocations. Therefore, the implementation of this study sheds some lights on the following research questions:

Q1: Does implementing focus on form tasks (dictogloss) have any effect on development of collocations among Iranian pre-intermediate learners?

Q2: Will meaning-focused tasks (discussion) lead to the development of significantly large number of collocations?

\section{Methodology}

\subsection{Participants and Setting}

The participant in this study were 65 female high school students (3rd \& 4th grades, aged 17-19) at Mashhad high schools ((Farvardin, Rahpoyan Elm, and Rabee) in Iran. . Almost all students in these high schools had not attended English classes in English Language Institutes, and All of them were enrolled in classes during the summer quarter of 2009, a period 6.5 weeks. They studied Interaction 1 Reading (kirn \& Hartmann, 2002) which is suitable for PreIntermediate level during 13 sessions.

Afterwards, they were divided into three groups of 20, 20, and 25 participants. One group was agreed to be held at Rabee high school, the other one at Farvardin high school and the third one at Rahpoyan Elm. Two groups, Farvardin and Rahpoyan Elm high schools, were chosen as the experimental groups and the other, Rabee high school, as the control group. Therefore, sixty five students were taught under three different conditions; each class randomly assigned to one condition: the form-focused instruction group $(\mathrm{N}=25)$, the meaning-focused instruction group $(\mathrm{N}=20)$, and the control group $(\mathrm{N}=20)$.

\subsection{Instrumentation}

First, the participants' general proficiency was assessed using the standardized 200A test of Nelson English Tests (book 2, Intermediate) to ensure the homogeneity of the groups at the very beginning of the course. The reliability of the tests was estimated by Cronbach's Alpha which is $(\mathrm{r}=.52)$. It consisted of three sections: cloze tests, structure, and vocabulary in the form of multiple choice questions. There were, in all, 50 items and the time allotted was 45 minutes. In this study, the reliability coefficient of this tests was high (Cronbach's Alpha: .81).

Second, self-designed achievement test of collocation was designed by the researcher to measure the gain scores of the learners in collocation as both pre-test and post-test (Appendix 1). It consisted of 40 multiple choice questions. The reliability of the tests was estimated by Cronbach's Alpha which is $(\mathrm{r}=.52)$. Content validity of test, also, was substantiated. To ensure the content validity of the collocation test, the researcher asked at least six teachers in order to check the adequacy of this test. At last, 40 multiple choice questions were chosen out of 50 .

\subsection{Procedure}

Over the course of 13 teaching sessions, the students were exposed to their course materials including Interaction 1 Reading (kirn \& Hartmann, 2002); the first four chapters of it studied. After administrating Nelson English language test and teacher-made collocation test, learners were divided into three different instructions: Two experimental groups: Form-Focused Instruction (Dictogloss task), Meaning-Focused Instruction (Discussion task), and control group.

In FFI group, (N-25), the teacher introduced the topic by asking indirect or direct questions about the text and showing related pictures in order to awaken their background knowledge. Then, students were asked to read a text paragraph by paragraph. The learners had no dictionary for unknown vocabularies. However, when learners wanted to ask the meanings of a word, the researcher would provide the necessary meaning of a word. When reading had been completed, the teacher went over the students and addressed any questions or comments from the learners. After completing the text, they received form-focused task, dictogloss. Firstly, the teacher modeled the steps of the process with students prior to asking them to co-construct a dictogloss on their own. In this task, teachers read a short text twice and at a normal speed to students (Appendix 2). The students listened very carefully and wrote down as much information as they could as they listen. When the reading had been finished, the students divided into small groups of three and were asked to use their notes in order to reconstruct the text as closely as possible to the original version. At last, they were asked to compare and analyze the different versions they had produced.

In the second experimental group, MFI (N-20), the first part of this treatment is similar to the FFI group. Firstly, the teacher talked about the topic in order to awaken learners' background knowledge. Then, the teacher asked students to read a text paragraph by paragraph. Learners stated the main idea of each paragraph, and the teacher answered any questions or comments about words' meaning from the learners. Upon the completion of the text, learners received communicative task, pair/ group discussion task. The teacher gave discussion topics based on the text 
(Appendix 3). First, learners worked in pairs, and discuss the topic. Following pair work, the entire groups discussed the topics in class.

Within the control group (N-20), the teacher discussed the topic of the text in order to activate learners' knowledge. Students read the text paragraph by paragraph silently, and afterward the teacher provided learners with new words and paraphrased the text. Assignments, then, included a text which was summarized by the students, a paraphrase written by learners and questions related to that text. The role of the teacher and students was so obvious in this study. The teacher was the dominant power in the classroom and the only source of knowledge and students were passive recipients of knowledge presented to them.

On the last session in all three classes, the teacher-made collocation test (Appendix 1) was administered as the posttest of the learners' achievement in collocations.

\section{Results}

In order to answer the research questions regarding the difference between the three different instructions, this study carried out three one-way ANOVAs. Each ANOVA compared the difference of means between the three conditions in the case of collocations in language ability test, pretest and posttest in experimental and control groups.

In order to ensure the homogeneity of groups at the very beginning of the term, on-way ANOVA was used. Table 1 shows that there is no significant difference among the three groups, experimental and control groups, regarding their language proficiency: $(\mathrm{F}=2.010, \mathrm{p}>0.05)$. The results show P-Value equals 0.143 which is more than $\alpha=$ 0.05 :

$$
\text { P-Value }=0.143>\alpha=0.05 \rightarrow \text { Accept } \mathrm{H}_{0}
$$

To ensure the homogeneity of groups with respect to collocations, one-way ANOVA was used. As table 2 shows there is no significant difference $(\mathrm{F}=.746, \mathrm{p}>0.05)$ among three groups with respect to collocations. The results reveal P-Value equals 0.478 which is more than $\alpha=0.05$ :

$$
\text { P-Value }=.478>\alpha=0.05 \rightarrow \text { Accept } \mathrm{H}_{0}
$$

The teacher-made collocation tests were administered again in all three groups. Table 3 exhibits a significant difference among the three groups of learners with regard to the treatment that each group received: $(\mathrm{F}=12.25, \mathrm{p}<$ 0.05 ). So, it illustrates that the probability of P-Value is not statistically significant and low enough than $\alpha=0.05$; therefore, it is justified to reject null hypothesis:

$$
\text { P-Value }=.000<\alpha=0.05 \rightarrow \text { Reject } \mathrm{H}_{0}
$$

Obviously, confidence level of $\% 95$ rejects null hypothesis. It means that the difference between average scores of collocation knowledge in experimental group (Digtogloss) falls well within the acceptance level of our hypothesis and this occurs because experimental group (Digtogloss) enjoys higher average score than control group and experimental group (Discussion).

As evident it in the Table 3.b, the highest ranking was assigned to the experimental group who received dictogloss task (32.20), with the experimental group who gained Discussion task (29.15) and the control group learners (27.65) tying respectively for the second ranking and the last place. The results show that students who used dictogloss task seem to outperform than the other two groups of participant, Con. group and Exp. Group (Discussion).

\section{Conclusion}

This study investigated whether incorporating FFI (digtogloss task) into a text-based communicative lesson would make a significance difference in the development of collocations by comparison between a reading comprehension task alone, and by comparison with a conventional group. The result revealed that the FFI group (dictogloss task) scored significantly higher than the two other groups in post-test. In contrast, the MFI group (pair/ group Discussion task) and the control group are approximately in the same position.

One of the great challenges for foreign language teachers has been the implementation of procedures that help learners process comprehensible input while at the same time giving them opportunities for language awareness. In other words, effective language teaching requires input processing and acquisition, which is combined with focus on 
form (Bourke, 2008). Language awareness has to do with the raising of learners' awareness of features of the TL. Hence, the teacher's role is no longer "all knowing one", but that of the "facilitator of leaning".

The second point is that the teachers should realize the value of collaborative work for learners' language learning. It gives them a strong sense of motivation and accomplishment. Speakers should engage in problem solving and knowledge building which is called collaborative dialogue (Swain, 2000, cited in Ellis, 2008). Learners can assist each other to perform the task which they do not handle by themselves. In other words, students tend to stick with the knowledge they co-constructed collaboratively. Such results strongly suggest that when students reflect consciously on the language they are producing, this may be a source of language learning.

Moreover, recent studies in second language pedagogy support the use of tasks which require learners to produce output collaboratively. Kowal and Swain (1994) and Swain and Lapkin (2001) argued for the use of collaborative tasks that students work in pairs or small groups. They claimed that through talk in collaborative task, learners notice their linguistic problems. Therefore, learners engage in making meaning clearer by discussing language forms in their dialogue. Thus, Collaborative output tasks promote learners to interact with each other resulting in collaborative dialogue which has been shown to positively affect second language development (cited in Garcia Mayo, 2002).

One of the main goals of dictogloss is to create a situation where students take notice of the gap that exist between the current state of linguistic competence in their output, IL and the TL (Shak, 2006).

Swain (1999, p.145) observed that "Students gain insights into their own linguistic shortcomings and develop strategies for solving them by working through them with a partner." This process which includes cognitive comparison tends to raise learners' awareness of certain grammatical structures. In addition; it reformulates their hypotheses of the structures as they modify their output (cited in Shak, 2006).

The third point is that a task that elicits meta-talk from one group of learners may not do so from another group; this may be due to the level of learners' proficiency, the age of the learner and so on. Moreover, Swain (1995) stated that three functions of output are noticing, hypothesis formulation and testing, and meta-talk or meta-linguistic (reflective) in second language learning. Firstly, noticing declares that a form used in input must be consciously noticed in order for it to be acquired. Noticing should be occurred during language production, while attempting to use the TL. Researchers have noted the importance of learners' noticing the gap in their IL that is noticing the difference between what they want to say and what they are able to say. Therefore, learners are attempting to produce the second language and they consciously notice that there are holes in their knowledge. The second function is hypothesis formulation and testing, learners may use language production as a way of trying out new language forms and structures as they stretch their IL; they may use their output to test what works and what doesn't. So, learners try out something and then maintain or modify it on the basis of perceived success and feedback. The last function is Meta-talk, learners use language to reflect on language use. It's a surfacing of language used in problem-solving; for cognitive purposes. Meta-linguistic (reflective) function involves largely spoken output being used to solve language problems in collaboration with others (cited in Nation, 2007).

Production of Meta-talk in the context of making meaning may deepen the students' awareness of forms and rules and the relationship of those forms and rules to the meaning they're trying to express. Common classroom applications of this idea include the use of activities like the strip story and dictogloss where learners work together to construct or reconstruct a text. These activities involve a lot of talk about language and this talk can contribute to language learning (Swain \& Lapkin, 1998, cited in Nation, 2007).

Finally, familiarity with the task procedures is a key point in the accurate accomplishment of the task. So, teacher modeling and role-playing of the activity is useful at the first sessions of instruction. Moreover, it is critical to provide students with feedback due to the fact that students tend to remember their incorrect solutions. Therefore, the teacher needs to be available during collaborative activities and attend to the accuracy of the final product. Thus, shelhe is a facilitator of learning process. In other words, students tend to stick with the knowledge they had co-constructed collaboratively. Such results strongly suggest that when students reflect consciously on the language they are producing, this may be a source of language learning.

\section{References}

Bourke,J. M.(2008) .A rough guide to language awareness. English teaching forum, 2, 12-21.

De la Fuente, M. J. (2006). Classroom L2 vocabulary acquisition: investigating the role of pedagogical tasks and form-focused instruction. Language teaching Research, 10, 263-295.

Doughty, C., \& Williams, J. (Eds.). (1998). Focus on form in classroom second language acquisition. Cambridge: Cambridge University Press. 
Ellis, R. (2000). 'Task-based research and language pedagogy'. Language Teaching Research, 4, 193- 220.

Ellis, R., (2001). Investigating form-focussed instruction. In: Ellis, R. (Ed.), Form Focused Instruction in Second Language Learning. Blackwell, Oxford (in press).

Ellis, R. (2003). Task-based language learning and teaching. Oxford: Oxford University Press.

Ellis, R. (2008). The study of second language acquisition. Oxford: Oxford University Press.

Ellis, R., Basturkmen, H., \& Loewen, S. (2001). Preemptive focus on for in the ESL classroom. TESOL Quarterly, 35,407-432.

Ellis, R., Basturkmen, H., \& Loewen, S. (2002). Doing focus-on-form. System, 30, 419-432.

Ellis R., Basturkmen, H., \& Loewen, S. (2006). Disentangling Focus on Form. A response to Sheen and O'Neill (2005). Applied Linguistics, 27,135-141.

Fowler,w.s.,\& Coe,N.(1976). Nelson English Language Tests. (Book 2, Intermediate). London:Butler \& Tanner Ltd.

Garcia Mayo, M.P. (2002). The effectiveness of two form-focused tasks in advanced EFL pedagogy. International Journal of Applied Linguistic, 12, 156-175.

Kirn,E., \& Hartmann,P.(2002). Interaction 1 Reading. New York: McGraw-Hill Company.

Long, M., \& Robinson, P. (1998). Focus on form: Theory, research and practice. In C.

Doughty \& J. Williams (Eds.), Focus on form in classroom second language acquisition (pp. 15-41). Cambridge, England: Cambridge University Press.

Loewen, S. (2003). Variation in the frequency and characteristics of incidental focus on form. Language Teaching Research, 7, 315-345.

Long, M. H. (1991). Focus on form: A design feature in language teaching methodology. In K. de Bot, R. Ginsberg, \& C. Kramsch (Eds.), foreign language research in cross-cultural perspective (pp. 39-52). Amsterdam: John Benjamins.

Nation , P.(2007). The four strand. Innovation in Language Learning and Teaching, 1, 1-13.

Norris,J.,Ortega,L.,(2000). Effectiveness of L2 instruction: a research synthesis and quantitative meta analysis. Language Learning, 50, 417-528.

Paradowski, M.B. (2007) .Utility of formal instruction and focus on form in language teaching. Exploring the L1/L2 Interface. A Study of Polish Advanced EFL Learners. Institute of English Studies, University of Warsaw, 64-85.

Shak, J. (2006). Children using dictogloss to focus on form. Reflections on English Language Teaching, 5(2), 47-62.

Wajnryb, R. (1990). Grammar dictation. Oxford: Oxford University Press.

Table 1. Results of One-way ANOVA for Nelson English Language Test

\begin{tabular}{l|l|l|l|l|l}
\hline & Sum of Squares & $d f$ & Mean Squares & $F$ & Sig. \\
\hline Between Groups & 21.378 & 2 & 10.689 & 2.010 & .143 \\
\hline Within Groups & 329.760 & 62 & 5.319 & & \\
\hline Total & 351.138 & 64 & & & \\
\hline
\end{tabular}

Table 2. Results of One-way ANOVA for Teacher- made Collocation Test in Pre-test

\begin{tabular}{l|l|l|l|l|l}
\hline & Sum of Squares & $d f$ & Mean Squares & $F$ & Sig. \\
\hline Between Groups & 14.74 & 2 & 7.37 & .746 & .478 \\
\hline Within Groups & 14.74 & 62 & 9.88 & & \\
\hline Total & 627.44 & 64 & & & \\
\hline
\end{tabular}

Table 3.a. Results of One-way ANOVA for Teacher- made Collocation Test in Post-test

\begin{tabular}{l|l|l|l|l|l}
\hline & Sum of Squares & $d f$ & Mean Squares & $F$ & Sig. \\
\hline Between Groups & 244.65 & 2 & 122.32 & 12.25 & .000 \\
\hline Within Groups & 619.10 & 62 & 9.98 & & \\
\hline Total & 863.75 & 64 & & & \\
\hline
\end{tabular}


Table 3.b .Results of Scheffe post hoc test for Teacher- made collocation test in Posttest

\begin{tabular}{l|l|l|l}
\hline \multirow{2}{*}{ Groups } & \multirow{2}{*}{$\mathrm{N}$} & \multicolumn{2}{|c}{ Subset for alpha $=.05$} \\
\cline { 3 - 4 } & & 1 & 2 \\
\hline Control group & 20 & 27.65 & \\
\hline Experimental group (Discussion task) & 20 & 29.15 & 32.20 \\
\hline Experimental group (DT) & 25 & & 1.000 \\
\hline Sig. & & .306 & \\
\hline
\end{tabular}

Appendix(1):Teacher-made Collocation Test

\section{Choose the best answer.}

1) He ........ serious heart attack, so he should not eat fat and greasy food.

a) catches b) has c) gets d) takes

2) A: I am not really in the mood for the party. I catch cold.

B: Take this pill; it may have GOOD effect ..... your health.

a) on b) at c) within d) out

3) Most of the students ...... the Internet courses this year in our university.

a) connect b) take c) get d) give

4) As she works hard these days, she tired and want to sleep. .

a) has b) gets c) remains d) takes

5) There was a(n) ...... wind blowing.

a) quick b) heavy c) serious d) strong

6) People try to cut ...... lots of trees in the jungles and build houses in the big cities. a)out b) down c) off d) from

7) She suddenly stopped at the intersection and a right turn.

a) had b) got c) passed d) made

8) We are looking for somebody with a clear of direction.

a) taste b) feature c)point d) sense

9) It was clear from Luke's ......... language that he was nervous and angry. His face turned red.

a) second b)verbal c) first d ) body

10) You should stop at the intersection, when the traffic is red.

a) lamp b) light c) flash d) bulb

11) Only $25 \%$ of students who ..... English test, passed the exam.

a) got b)used c) took d) made

12) They hadto accept the law the public pressure.

a) in addition to b) in response to c) in order to d) because

13) The information available to anyone who wishes to see it.

a) feels b) gets c) is d)looks

14) Mina a great idea for a present for Lora.

a) tells b) offers c) states d) has

15) I am going to give a (n) .......... about the importance of education in our country.

a) preparation b) lecture c) observation d) conversation

16) Most of old people may suffer from low. pressure in the warm weather.

a) work b) social c) blood d) vessel 
17) In our English class, only seven students are able to the class.

a) present b) get c) do d) attend

18) Students should charge tuition to the colleges in order to study there.

a) rent b)payment c) fee d) salary

19) The job finding centers help to find out newest job chances.

a)around b) over c)about d) for

20) I have to an exit exam in order to accept in the university.

a) get b) give c) take c) have

21) A: Can you . me some advice about buying a house? I really need it.

B: Sure. How much money do you have?

a) tell b)state c) make d) give

22) They can get ...... aid like loan. These students have lots of problems, so it may help them.

a) formal b) educational c)financial d)basic

23) The teacher a history assignment to students, they should write it carefully.

a) got b)gave c)did d)took

24) David is in bed, he may the flu. He could not go to the university today.

a) hold b) take c)feel d)get

25) It doesn't sense why she should do this action.

a) take b) get c)give d)make

26) David invited us to his birthday party and we a lot of fun at his party.

a) gained b) had c)passed d) took

27) Let's get popcorn at the snack .It is not far from here.

a) station b)stop c) store d)bar

28) There are many things to see in Mashhad the Holy Shrine of Emam Reza.

a) in contrast b) instead of c) for instance d)according to

29) Most office worker prefers food to a sit-down meal in a restaurant. It is a quick and easy meal.

a) natural b) quick c)healthy d) snack

30) A: You become very fat, so you should go a diet.

B: Sure, The doctor asked me to eat small amount of food during a day.

a) on be) for c) in d) into

31) I forgot to return library books on time, so I must a fine for it.

a) make b)have c) spend d) pay

32) The driver a ticket for going through a red light.

a) gives b)gets c) buys d) makes

33) When you want to go on a trip, take this map. So, you will not lost.

a) have b) get c) become d)take

34) David was very fat, but he is weight now. He looks very handsome.

a) Putting b) losing c) holding d) missing

35) Mina is still in contact with Sarah. They are old high school friends.

a) near b) close c) nice d)nearby

36) Can you .me a direction for getting to John's house? 
a) give b) take c) state d) tell

37) You look very dangerous, try to stay ........ d do not want to see you again.

a) around b)on c) in d) away

38) Could you fill the glass .... water? I am thirsty.

a) in b) of c) with d) out

39) The life situation can vary completely country country.

a) between-with b) among-to c) from-to d) between-to

40) Mr. Smith was forced to ....... high fee for his lawyer's work. It was so expensive.

a) pay b)give c) take d) spend

\section{Appendix (2) Dictogloss Text}

Dictogloss Text (1)

Hossien is an international student; He leaves his home country and went to USA. This year, he takes English and internet courses and attends classes with his friend Mark. They study hard and take many exams. In their class, they must give a lecture. Their teachers give assignment and get advice if they need it.

Dictogloss Text (2)

Hossien should pay tuition fee to the university and he, also, can get financial aids like loans. In addition, learning resources and recreation are available to students in their university such as computer center. So they have lots of fun.

\section{Dictogloss Text (3)}

The weather condition may vary from month to month .It may have powerful effect on people's health, thinking and feeling. The strong wind and warm weather increase the blood pressure, and many people may have heart attack in response to strong wind. In the winter they may get the flue because they are in close contact indoors in cold weather. Moreover, they are more depressed and get tired easily in winter.

\section{Dictogloss Text (4)}

The temperature of the earth is growing up and the human being is the main reason of global warming. He cuts down trees and puts up building instead of trees.

\section{Dictogloss Text (5)}

Hossien had a fat roommate, David. Most of the time, he went to snack bars and ate fast and snack food. This food fills with lots of fat and cholesterol. Recently he had a heart attack and the doctor tells him "You must go on a diet and lose your weight". Now he has an eating plan and stay away from fast and snack food which he likes too much!

Dictogloss Text (6)

Hossien went on a trip to Greece. He wanted to go to the post office, but he got lost. He doesn't have a good sense of direction, so he asks for direction. The man said "sorry, I had no idea", and walks away quickly. Then, he asks the other man; he tries to give direction with body language. He turns and then points. Finally, Hossein found out about the direction.

\section{Dictogloss Text (7)}

Laws are rules for people in communities. These laws make sense, they are necessary for safety and health. Traffic laws vary in community around the world. For instance, in USA, drivers can make write turns after a full stop at a red traffic light. In some countries you can get a ticket for only jaywalking. So, you have to pay an expensive fine.

\section{Appendix (3) Discussion Task}

Discussion Task (1)

With your partner discus the following question: Do you like to go abroad? Which country do you like to go?

Discussion Task (2)

With your partner discus the following statement: Talk about different kinds of university classes around the world: student's life, system of education and teaching style. Which kinds of university classes do you like?

Discussion Task (3) 
With your partner discus the following statement: Weather can influence people's health, mind, and mood. Some kind of weather such as sunny, windy snowy and so on influence human's health. Agree or disagree.

Discussion Task (4)

With your partner discus the following statement: The global diet is changing nowadays. Agree or disagree.

Discussion Task (5)

With your partner discus the following question: What is your idea about good food and nutrition? Do you think there is a perfect diet for health and long life?

Discussion Task (6)

With your partner discus the following statement: Communities' or countries' rules such as traffic, driving, smoking and even relationships laws are necessarily for human. Agree or disagree.

Discussion Task (7)

With your partner discus the following question: How do most people give direction your city? Do you give direction the someway 